\title{
Potentialization of antioxidant activity of Piper umbellata (Piperaceae) leaves after their metabolism in Heraclides brasiliensis larvae (Lepidoptera: Papilionidae)
}

\author{
Clécio S. Ramos ${ }^{\star}$, Andra J. L. N. Paz, Telma M. G. da Silva and Tânia M. S. da Silva \\ Department of Molecular Sciences, Rural Federal University of Pernambuco, Recife - PE, Brazil.
}

Accepted 19 June, 2012

\begin{abstract}
Piper umbellata leaves accumulate the compound, 4-nerolidylcatechol, which is responsible for the antioxidant power of the plant. Surprisingly, in this study we observed a significant increase in the antioxidant activity of $P$. umbellata leaves after their metabolism on Heraclides brasiliensis larvae. The total phenolic concentrations of the extracts from the leaves and fecal matter (metabolized leaves) measured using the Folin-Ciocalteu reagent, were 14.78 and $27.13 \mathrm{mg} \mathrm{GAE} / \mathrm{g}$, respectively. The antioxidant activity, based on 2,2-azinobis 3-ethylbenzothiozoline-6-sulfonic acid (ABTS), was EC $\mathrm{C}_{50}$ of 120.10 and $62.50 \mathrm{ug} / \mathrm{ml}$ for the leaves and fecal material, respectively. These values were correlated with the total phenolic content.
\end{abstract}

Key words: Piper umbellata, Heraclides brasiliensis, antioxidant, metabolism.

\section{INTRODUCTION}

Piper umbellata (L.) Miq. (Piperaceae) [syn. Heckeria umbellata (L.) Kunth., Pothomorphe umbellata L., Piper hilarianum Stend.], known popularly as "caapeba" in Brazil and "cowfoot" in English speaking countries, has been reported to be a potent antioxidant (Kijjoa et al., 1980). This antioxidant activity of $P$. umbellata is attributed to its major constituent, 4-nerolidylcatechol (1), detected in its root and leaf tissues (Pinto et al., 2010; Ropke et al., 2003; Noriega et al., 2008a; b). Others minor compounds (N-p-coumaroyl tyramine, piperumbellactam $\mathrm{A}, \mathrm{B}$ and $\mathrm{C}$ ) isolated of $P$. umbellata branches showed antioxidant activity (Tabopda et al., 2008). The compound 1 is biotransformed to $E-2,3-$ dihydro-3-(3,4-dihydroxyphenyl)farnesoic (2) during metabolism of the leaves by Heraclides brasiliensis, a host insect (Figure 1) (Ramos et al., 2012). Whereas alterations in the chemical profile of plant tissues can

${ }^{*}$ Corresponding author. E-mail: clecio@dcm.ufrpe.br. Tel/Fax: +55 81-33206317. drastically affect their various biological proprieties, the present work aimed to evaluate the antioxidant properties of $P$. umbellata leaves after their metabolism in $H$. brasiliensis.

\section{MATERIALS AND METHODS}

Chemicals

Folin-Ciocalteu's phenol reagent, potassium persulfate and 6hydroxy-2,5,7,8-tetramethylchroman-2-carboxylic acid (Trolox) were obtained from Sigma-Aldrich (Steinheim, Germany), and 2,2azinobis 3-ethylbenzothiozoline-6-sulfonic acid (ABTS) was supplied by Fluka Chemie (Buchs, Switzerland).

Botanical and entomological materials

Leaves of $P$. umbellata were collected in the city of Itabuna, Bahia, Brazil, in November 2011. A voucher specimen was deposited in the herbarium of the Institute of Biosciences of the University of São Paulo, under code KATO-671. This plant was authenticated by Dr. Elsie F. Guimarães of the Jardim Botânico Research Institute in Rio de Janeiro, RJ, Brazil. Larvae of $H$. brasiliensis were collected 

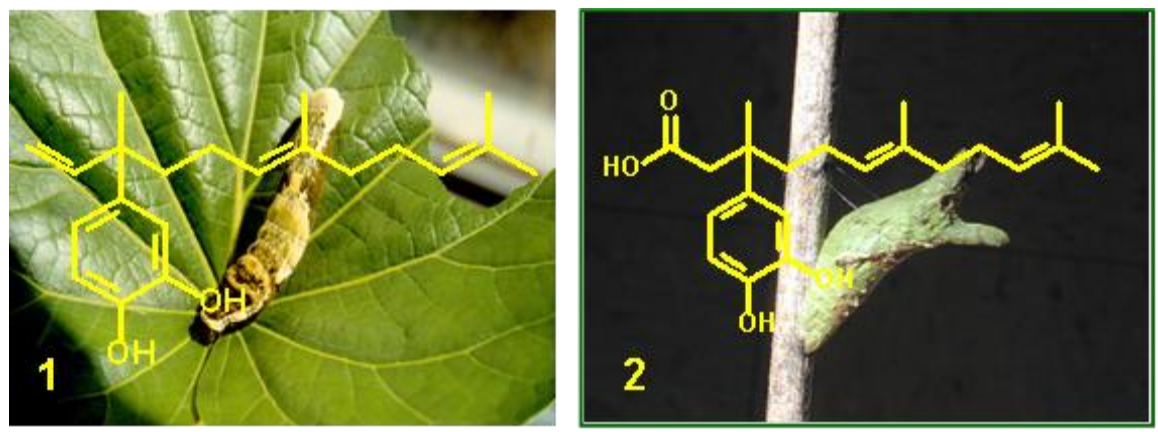

Figure 1. Chemical structures of compounds 1 (4-nerolidylcatechol) and 2 (E-2,3dihydro-3-(3,4-dihydroxyphenyl)farnesoic), larvae and pupae of $H$. brasiliensis in $P$. umbellata.

Table 1. Results of antioxidant activity of leaves and fecal extracts.

\begin{tabular}{lcc}
\hline Extract & Total phenol $\mathbf{~ g ~ E A G / g ~} \pm$ DP & ABTS EC $_{50}(\mathbf{u g} / \mathbf{m l}) \pm \mathbf{D P}$ \\
\hline Leaves & $14.78 \pm 3.29$ & $120.10 \pm 1.70$ \\
Fecal & $27.13 \pm 4.53$ & $62.50 \pm 0.60$ \\
Trolox & - & $1.95 \pm 0.02$ \\
\hline
\end{tabular}

$\mathrm{mg} \mathrm{EAG} / \mathrm{g}=\mathrm{mg}$ of gallic acid per $\mathrm{g}$ of extract; $\mathrm{EC}_{50}=$ effective concentrations.

collected from $P$. umbellata in November 2011 in Itabuna and identified by Dr. Sérgio Antônio Vanin of the Zoology Department of the Biosciences Institute of the University of São Paulo. A voucher specimen (CSR 006) was deposited at the Zoology Museum of the University of São Paulo.

Dried leaves of $P$. umbellata $\left(10 \mathrm{~g}, 40^{\circ} \mathrm{C}\right.$ for $\left.48 \mathrm{~h}\right)$ were milled and subjected to ethanol extraction $(120 \mathrm{~m})$ twice, and then concentrated in a vacuum to yield $0.91 \mathrm{~g}$ of crude extract. Five individuals of $H$. brasiliensis were collected on $P$. umbellata leaves and were maintained in cages for a month under a diet consisting of $P$. umbellata leaves, with feces collected daily. Dried feces $(2 \mathrm{~g}$, $40^{\circ} \mathrm{C}$ for $\left.48 \mathrm{~h}\right)$ were milled and subjected to two methanol extractions $(100 \mathrm{ml})$, which after concentration in a vacuum yielded $0.25 \mathrm{~g}$ of crude extract.

\section{LC-MS Analysis}

HPLC analysis of extracts and pure compounds was performed with a Shimadzu chromatograph model SCL-10A with UV-VIS detector, using a Supelco reversed phase column. Elution was carried out in a gradient mode starting with acetonitrile:water (4:6) for $10 \mathrm{~min}$, rising to $(9: 1)$ in $30 \mathrm{~min}$ and maintained for to $35 \mathrm{~min}$. The flow rate was $1 \mathrm{~mL} / \mathrm{min}$; injection volume $20 \mu \mathrm{L}$; UV scan, $200-400 \mathrm{~nm}$, and all chromatograms were obtained at $\lambda \max =214 \mathrm{~nm}$.

\section{Antioxidant activity}

Significant levels of antioxidant activity of the leaf and fecal extracts were found using 2,2'-azino-bis(3-ethylbenzthiazoline-6-sulfonic acid) $\left(\right.$ ABTS $\left.^{\bullet+}\right)$ radical scavenging assays $\left(\right.$ ABTS $^{\bullet+}$ scavenging method). The 1,1-diphenyl-2-picrylhydrazyl radical (DPPH•) scavenging activity of the isolated compounds was measured as reported in the literature (Slinkard and Singleton, 1977) with some modifications. Briefly, $\mathrm{ABTS}^{\bullet+}$ was generated by reacting ABTS solution $(7 \mathrm{mM})$ with potassium persulphate $(2.45 \mathrm{mM}$, final concentration) for 12 $16 \mathrm{~h}$ in the dark at room temperature. Then, the $\mathrm{ABTS}^{\bullet+}$ solution was diluted with ethanol to obtain absorbance of $0.70( \pm 0.02)$ at $734 \mathrm{~nm}$ and further equilibrated at $30^{\circ} \mathrm{C}$. The fecal and leaf extracts were diluted in ethanol at a concentration of $1 \mathrm{mg} / \mathrm{ml}$, and the ABTS $^{\circ+}$ solution was added to both extracts to obtain concentrations of 1.0 to $100.0 \mu \mathrm{g} / \mathrm{ml}$. The absorbance of the reaction mixture was measured at $734 \mathrm{~nm}$ after reaction at room temperature for 10 min. Trolox was used as positive control. The capability of scavenging the ABTS+• radical was calculated using the following equation:

ABTS $^{\bullet+}$ scavenging effect $(\%)=\left[\left(A_{0}-A_{1} / A_{0}\right) \times 100\right]$

where $A_{0}$ is the initial concentration of $A_{B T S}{ }^{++}$and $A_{1}$ is the absorbance of the remaining concentration of $\mathrm{ABTS}^{\bullet+}$ in the presence of the sample.

\section{Total phenolic content}

The total phenolic content of the fecal and leaf extracts was determined using the Folin-Ciocalteu reagent according to the method of Slinkard and Singleton (Duh et al., 1999), modified by the use of gallic acid as a standard phenolic compound. Appropriate amounts of extracts $(500 \mu \mathrm{L} ; 50 \mu \mathrm{g} / \mathrm{mL})$ were diluted in a volumetric flask with distilled water $(3 \mathrm{ml})$. The Folin-Ciocalteu reagent $(100 \mu \mathrm{L})$ was added and the contents of the flask were thoroughly mixed. After $3 \mathrm{~min}, \mathrm{Na}_{2} \mathrm{CO}_{3}(15 \%, 300 \mu \mathrm{L})$ was added and the mixture was completed with distilled water $(5 \mathrm{ml})$ and allowed to stand for $2 \mathrm{~h}$ in an ultrasonic bath. The absorbance was measured at $760 \mathrm{~nm}$ in a spectrophotometer. The total amount of phenolic compounds was determined in micrograms of gallic acid equivalents, using the equation obtained from the standard gallic acid graph.

\section{RESULTS AND DISCUSSION}

The chemical profiles of the leaf and fecal extracts obtained 
obtained by LC-MS indicated that compounds 1 and 2 are major constituents, respectively, as previously reported. The evaluation of the biological activity of both extracts showed that the antioxidant activity of the metabolized $P$. umbellata leaves (fecal extract), as determined by the total phenol and $\mathrm{ABTS}^{\bullet+}$ methods, was higher than that of the leaves (Table 1). The results indicated that the leaf and fecal extracts of $P$. umbellata both possess potent antioxidant activity. However, the fecal extract was twice as active as the leaf extract. There was a direct correlation between the phenolic content and the antioxidant activity of the fecal and leaf extracts because phenolic compounds contribute directly to antioxidant activity ( $R e$ et al., 1999; Chowdhury et al., 2012). The higher total phenolic content observed for the fecal extract can be associated with the release of phenolic compounds linked to the leaf cell walls during the insect's digestive process.

In summary, the potentialization of the antioxidant activity of leaves of $P$. umbellata after metabolism in $H$. brasiliensis can be associated with the biotransformation of compound $\mathbf{1}$ into $\mathbf{2}$ as well as the increase of the total phenolic content of the fecal extract. This study type contributes to the discovery of new natural bioactive compounds because it describes, for the first time as a novelty, the modification of a natural source $(P$. umbellata leaves) with potent antioxidant activity by insect.

\section{ACKNOWLEDGEMENTS}

This work was supported by grants from FACEPE. We also thank Dr. Elsie F. Guimarães and Dr. Sérgio Antônio Vanin for the identification of the plant and insect species, respectively.

\section{REFERENCES}

Chowdhury SR, Tasdique FI, Quadery M, Shihan MH, Rashid MA (2012). In vitro antioxidant, total phenolic content and preliminary toxicity studies of Gmelina philippensis chem. Afr. J. Pharm. Pharmacol. 6:855-859.

Duh PD, Tu YY, Yen GC (1999). Antioxidant activity of water extract of Harng Jyur (Chrysanthemum morifolium Ramat). Food Sci. Technol. 32:269-277.

Kijjoa A, Giesbrech AM, Akisue MK, Gottlieb OR, Gottlieb HE (1980). 4Nerolydilcatechol from Pothomorphe umbellata. Planta Med. 39:8587.

Noriega PR, Cristina D, Consiglieri VO, Taqueda MÊS, Tavares LC, Wasicky A, Bacchi EM, Barros SBM (2008a). Optimization of Pothomorphe umbellata (L.) Miquel topical formulations using experimental design. Int. J. Pharm. 353:149-159.

Noriega PR, Cristina D, Consiglieri VO, Taqueda MÊS, Tavares LC, Wasicky A, Bacchi EM, Barros SBM (2008b). Optimization of Pothomorphe umbellata (L.) Miquel topical formulations using experimental design. Int. J. Pharm. 353:149-159.

Pinto ACS, Chaves FCMS, Pierre A, Nunez CV, Tadei WP, Pohlit AM (2010). Piper peltatum: biomass and 4-Nerolidylcatechol production. Planta Med. 76:1473-1476.

Ramos CS, Souza LJ, Kato MJ, Batista R (2012). Biotransformation of 4-nerolidylcatechol by Heraclides brasiliensis (Lepidoptera: Papilionidae) reduces the toxicity of Piper umbellata (Piperaceae). Chemoecology, 22:39-45.

Re R, Pellegrini N, Proteggente A, Pannala A, Yang M, Rice-Evans C (1999). Antioxidant activity applying an improved ABTS radical cation decolorization assay. Free Radical Biol. Med. 26:1231-1237.

Ropke CD, Meirelles RR, Da Silva VV, Sawada TCH, Barros SBM (2003). Pothomorphe umbellata extract prevents $\beta$-tocopherol depletion after UV-irradiation. Photochem. Photobiol. 78:436-439.

Slinkard K, Singleton VL (1977). Total phenol analyses: Automation and comparison with manual methods. Am. J. Enol. Vitic. 28:49-55.

Tabopda TK, Ngoupayo J, Liu J, Mitaine-Offer AC, Tanoli SAK, Khan SN, Ali MS, Ngadjui BT, Tsamo E, Lacaille-Dubois MA, Luu B (2008). Bioactive aristolactams from Piper umbellatum. Phytochemistry 69:1726-1731. 